\title{
The Co-Evolution of Institutional Logics and Boundary Spanning in Sustainability Transitions: the Case of Urban Stormwater Management in Melbourne, Australia
}

\author{
Christoph Brodnik ${ }^{1,2} \&$ Rebekah Brown ${ }^{3}$ \\ ${ }^{1}$ Cooperative Research Centre for Water Sensitive Cities, Monash University, Australia \\ ${ }^{2}$ School of Social Science, Monash University, 3800, Australia \\ ${ }^{3}$ Monash Sustainable Development Institute, Monash University, 3800, Australia \\ Correspondence: Christoph Brodnik, Monash University, Building 11a, Clayton, VIC 3800, Australia. Tel: \\ +61-403-796-986. E-mail: Christoph.brodnik@monash.edu
}

Received: June 3, 2017

Accepted: July 24, 2017

Online Published: August 7, 2017

doi:10.5539/enrr.v7n3p36

URL: https://doi.org/10.5539/enrr.v7n3p36

\begin{abstract}
Institutions and actors both play a critical role in sustainability transitions, yet they have never been investigated together. This study combines both dimensions, systematically applying an institutional logics and boundary spanning lens to examine the interplay between structure and agency over the course of a particular system innovation: the case of urban stormwater management in Melbourne, Australia. Looking through this dual lens reveals the socio-institutional patterns and mechanisms that determine inertia and practice change in the urban stormwater management system. We found that structure and agency co-evolve; when their relationship changes, the dynamics between boundary spanning and institutional logics change too - as do the corresponding niche and regime developments. Our findings suggest that even radical innovations can be successfully institutionalized when using certain forms of boundary spanning at specific phases of a system innovation.
\end{abstract}

Keywords: boundary spanning, institutional logics, sustainability transitions, urban water management, water sensitive urban design

\section{Introduction}

Tackling the societal challenges of the twenty-first century requires urgent, system-wide change in sectors such as energy (Verbong \& Loorbach 2012), mobility (Geels et al., 2011), agriculture (Spaargaren et al., 2012) and water management (Pahl-Wostl, 2006). A number of different theoretical frameworks have been developed and are widely used to examine transitions at the system level - for example, the multi-level (Geels, 2004), multi-phase (Rotmans et al., 2001), and multi-pattern (de Haan and Rotmans, 2011) concepts. But how do transitions unfold at the actor level? The answer is less clear (Farla et al., 2012), with scholars arguing for a more practical and micro-scale explanation of change dynamics that focuses specifically on institutions and actors (Fuenfschilling \& Truffer, 2014; Grin et al., 2010; Smith et al., 2005; van den Bergh et al., 2011).

Different studies highlight the importance of institutions (e.g. Dolata, 2013; Fuenfschilling \& Truffer, 2014; Truffer et al., 2009) and actors (e.g. Huitema \& Meijerink, 2010; Loorbach and Rotmans, 2010; Timmermans et al., 2014; Westley et al., 2013) in systemic change processes. While established sociological theory emphasizes that these two dimensions are inextricably linked (Bourdieu, 1977; Giddens, 1984), they have mostly been examined separately in transitions research, with little attention paid to their interactions. This overemphasis on one dimension at the expense of the other reduces the explanatory power of institutional and agency theory and leads to one-sided views of inertia and practice change in socio-technical systems.

To address this gap in sustainability transitions research, this study interlaces both dimensions by investigating the dynamic relationship of structure and agency in an empirical case of transformative practice change: urban stormwater management in Melbourne. The case of Melbourne's urban stormwater management transformation has thus far been researched separately from an agency (Ferguson, Brown, de Haan, \& Deletic, 2014) or structural perspective (Ferguson, Brown, Frantzeskaki, de Haan, \& Deletic, 2013) which advanced our understanding on the importance of either dimensions. While research thus far touched on the relationship between different actions of 
actors and structural system elements (e.g. policy \& regulation) in the urban water management sector (e.g. Brown et al., 2013 or Werbeloff \& Brown, 2016) these studies do not systematically ground their analysis in institutional or agentic theory leaving the development and empirical testing of a conceptual framework that fully describes the co-evolution of structure and agency across the entire arch of a systemic change processes underdeveloped.

This paper systematically conceptualises the co-evolution of structure and agency across the entire trajectory of transformative practice change through the dual lens of institutional logics (IL) and boundary spanning (BS). Indeed, these concepts can fruitfully be used to analyse the interaction between institutions and actors in transitions (e.g. Smink, Negro, Niesten, \& Hekkert, 2015). While IL links institutional context and action, BS describes actors' strategic activities in diverse institutional working environments. Additionally, IL lends itself particularly well to transitions research, because it enables us to account for the social (e.g. norms and values) and material (e.g. technology) dimensions in niches and regimes (Fuenfschilling \& Truffer, 2014). In contrast, BS points to actors skilled at building bridges between divergent worlds by pursuing connective and mediating strategies - an approach deemed pivotal to advancing radical innovation in practice (Smink et al., 2015; Elzen et al., 2012; Kivisaari et al., 2013). Overall, both concepts offer a promising lens for the study of actors and institutions in transitions research, revealing the socio-institutional dynamics that can unlock path dependencies and help with the breakthrough, diffusion, and up-scaling of radical innovation in the face of competing and conventional practices. The research question for this study therefore is: How do institutional logics and boundary spanning agency co-evolve during systemic change? Our study answers this question and advances existing transition frameworks by painting a more nuanced picture of structure and agency in sustainability transitions. Insights from this research can be used to inform practice-based, policy-oriented innovation management and transition steering advice (e.g. Loorbach, 2010).

\section{Theoretical Background}

The concept of regime features prominently in a range of established frameworks that conceptualize and analyze transitional change from a systems perspective. The core idea is that regimes create a socio-technical configuration which guides incremental change along established pathways (Markard et al., 2012). While some scholars highlight the regime's institutional elements (Hoogman et al., 2002; Rip \& Kemp, 1998) others emphasize its technological component (Geels, 2004). Similarly, the concept of niche is fundamental to established frameworks because of its role in creating and supporting radical innovation. Niches are cast as a protective space, offering 'seeding conditions' for social and technical innovation to develop undisturbed by the prevailing regime's selection pressure (Kemp et al., 1998; Kemp et al., 2001).

\subsection{The Institutional Logics Perspective}

Institutional logics (in short: logics) are a set of principles specific to a certain organizational field (industry sector) (Note 1). They influence individuals' practices, interests, and identities by providing them with widely shared and legitimate means-end prescriptions (Thornton \& Ocasio, 2008). Individuals instantiate and carry logics through their behaviour and actions (Pache \& Santos, 2013); they continue to reproduce and sustain them, because logic compliance is rewarded by social legitimacy, while deviation is sanctioned (Rao et al., 2003). Importantly, logics do not only provide top-down orienteering principles but also bottom-up symbolic (ideation and meaning) and material (structure, practice, physical objects) building blocks with which actors operate (Thornton et al., 2012; Thornton \& Ocasio, 1999). This emphasis on both the social dimension and on material artefacts makes this literature well-suited to studying socio-technical phenomena.

The institutional characteristics of niches and regimes have been theorized most recently by Fuenfschilling and Truffer (2014), who conceptualize them with different institutional logics. Importantly, multiple logics structure socio-technical systems over time (Goodrick \& Reay, 2011). While their principles often conflict with each other (Smink et al., 2015), some studies also note a complementary relationship between different institutional logics (Daudigeos et al., 2013). Whether conflicting or complimentary, this relationship forms a constellation of logics that defines dominant and innovative practices in socio-technical systems. Ambiguity arises from this complexity: actors operate with a semi-coherent set of rules, through which they experience contestation and conflict in their actions (see Geels, 2004). Far from being homogenous entities, niches and regimes are a diverse and changing mix of system-specific institutional logics. Individual logics vary in strength based on how institutionalized they are, and how well they align with other logics (Figure 1) (Fuenfschilling \& Truffer, 2014). While regimes gravitate around dominant system logics characterized by highly institutionalized and coherent logic elements, niches gravitate around less developed or established ones. From this perspective we can conceptualize the transition of a socio-technical system as a gradual but holistic transformation of the institutional logics constellation that underpins regimes and niches. 


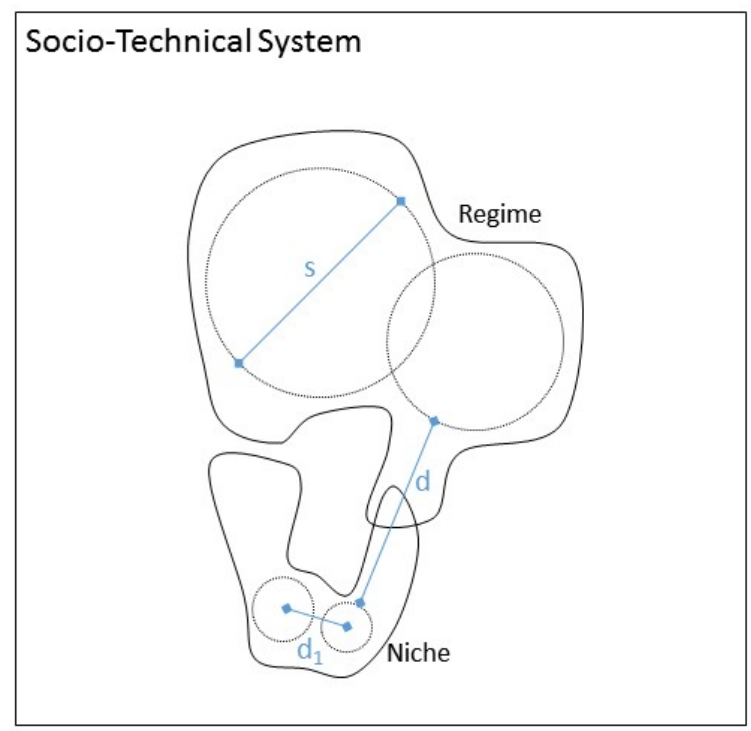

s (Size): Institutionalization of elements within a logic d \& $d_{1}$ (Distance): Coherence of elements between logics

Figure 1. Multiple institutional logics structure niches and regimes. The institutionalization of logic elements (s) and the coherence of elements between logics $\left(\mathrm{d} \& \mathrm{~d}_{1}\right)$ determine their strength and influence in a socio-technical system

In the notion of Figure 1, multiple logics structure socio-technical systems as well as their sub-systems (niches and regimes); both are characterized by institutional complexity. The possibility of agency fundamentally rests on this complexity, and on individuals' capacity to conceptualize and purposefully act upon alternative but equally legitimate ways of thinking and doing. As such the multiplicity of logics enables and constrains agency at the same time. Logic multiplicity enables agency by providing alternative rationalities; at the same time it constrains agency by determining which sector-specific principles and practices are legitimate. Actors who experience different institutional logics can critically engage with them and decide which aspects of a logic to enact and which ones to disregard. By doing so, actors decouple and recombine logic elements strategically, thereby altering existing practices, supporting new ones, and instigating institutional change.

\subsection{The Boundary Spanning Perspective}

Table 1. Boundary spanners' characteristics: attributes and ways of working

\begin{tabular}{|c|c|c|}
\hline Attributes & $\begin{array}{l}\text { Peripheral/mobile position: } \\
\text { No formal core position in an organization } \\
\text { or in a field, but strong linkages internally } \\
\text { and a high degree of legitimacy; situated at } \\
\text { the periphery of an organization or in } \\
\text { between organizations; showing } \\
\text { inter-organizational mobility }\end{array}$ & $\begin{array}{l}\text { Horizontal connectivity: } \\
\text { Specialized in one area, but broad working } \\
\text { knowledge of other areas (T-shaped } \\
\text { professionals); strong linkages with other } \\
\text { actors; sensitive and knowledgeable to } \\
\text { other ways of doing }\end{array}$ \\
\hline Ways of working & $\begin{array}{l}\text { Information management } \\
\text { Responsible for information exchange; } \\
\text { skilled in using different information } \\
\text { coding schemes; application of rhetorical } \\
\text { strategies to connect new information with } \\
\text { familiar interpretations of reality }\end{array}$ & $\begin{array}{l}\text { Network management } \\
\text { Working against fragmentation; facilitating } \\
\text { collaboration; creating connections } \\
\text { between actors, or resources and actors }\end{array}$ \\
\hline
\end{tabular}

How agency plays out is described in the microfoundations of the IL perspective (Thornton et al., 2012). Three mechanisms underpin this process: first, availability (what knowledge and information do individuals have about a given logic?); second, accessibility, (how easily do this knowledge and information about a given logic come to mind?); and third, activation (are the available and accessible knowledge and information actually used in social 
interactions, and if so, how is it triggered by focus of attention?). In essence, agency plays out at the micro level through the exchange, negotiation, and application of information that carries the symbolic and material aspects of different institutional logics. Through time, repetition, and socialization processes, information turns into widely shared, higher-order principles and eventually solidifies into the taken-for-granted (Thornton et al., 2012). In the next section we outline each of the three mechanisms and describe how boundary spanners operationalize them through their attributes and ways of working.

Boundary spanners have been analyzed and theorized in organizational and policy research (e.g. Langan-Fox and Cooper, 2014; Meerkerk \& Edelenbos, 2013; Williams, 2002, 2010) from which we draw to characterize them (Table 1). Building on this understanding we subsequently link these attributes and ways of working with the microfoundations of institutional logics and explain how a combination of boundary spanners' characteristics enables the use of the availability, accessibility, and activation mechanisms (Table 2).

Table 2. Microfoundations of institutional logics from Thornton et al. (2012), and how the mechanisms are operationalized by a combination of boundary spanners' attributes and ways of working

\begin{tabular}{|c|c|c|}
\hline Microfoundations of IL (individual level) & Description of mechanism & Operationalization by boundary spanners \\
\hline Availability & $\begin{array}{l}\text { Refers to the knowledge and information } \\
\text { that individuals have about a given logic }\end{array}$ & $\begin{array}{l}\text { Enabled by their peripheral position and } \\
\text { (inter-)organizational mobility which exposes } \\
\text { them to different rationalities (attribute); } \\
\text { realized through trans-boundary information } \\
\text { management and transmitting between the } \\
\text { 'right' network nodes (ways of working) }\end{array}$ \\
\hline Accessibility & $\begin{array}{l}\text { Refers to the degree to which knowledge } \\
\text { and information about a given logic may } \\
\text { come to mind }\end{array}$ & $\begin{array}{l}\text { Enabled by their horizontal connectivity } \\
\text { which makes them sensitive to other } \\
\text { information coding scheme (attribute); realized } \\
\text { through rhetorical mediation strategies that } \\
\text { connect new information with familiar } \\
\text { interpretations of reality (ways of working) }\end{array}$ \\
\hline Activation & $\begin{array}{l}\text { Refers to whether available and } \\
\text { accessible knowledge and information } \\
\text { are actually used in social interactions; } \\
\text { triggered by focus of attention }\end{array}$ & $\begin{array}{l}\text { Enabled by their peripheral and mobile } \\
\text { position and horizontal connectivity which } \\
\text { allows them to access alternative behaviour } \\
\text { and action schemas (attribute); realized through } \\
\text { channelling attention by connecting specific } \\
\text { schemas to issue at hand, or rhetorical } \\
\text { amplification strategies to increase the stimulus } \\
\text { of an event (ways of working) }\end{array}$ \\
\hline
\end{tabular}

\subsubsection{Availability}

Availability accounts for the knowledge and information that can be used by individuals in cognitive processes (Thornton et al., 2012). The existence of multiple institutional logics opens up the possibility for actors to tap into alternative ways of knowing and doing, which boundary spanners exploit in two ways. Boundary spanners' attributes mean they can conceptualize and act upon this heterogeneous institutional environment, which they do through their particular ways of working. While boundary spanners are highly trusted individuals familiar with the formal and informal norms of an organization and its field (Steadman, 1992; Williams, 2002), they often inhibit a peripheral position or show inter-organizational mobility (Meerkerk \& Edelenbos, 2013; Organ, 1971). This attribute enables boundary spanners to be more reflective and critical about routine behaviour, allowing them to discover and recognize the value of innovative practices (Organ, 1971; Williams, 2012b). They realize this critical potential through their trans-boundary information and network management skills: as subject-matter experts with a broad working knowledge, boundary spanners can access information from different contexts (Organ, 1971). At the same time they strategically manage networks to prevent fragmentation and siloes (Bressers and Lulofs, 2010; Edelenbos et al., 2013; Williams, 2002) by driving collaborations that transmit information between the 'right' network nodes (Bryson \& Crosby, 2006; Edelenbos et al., 2013). Overall, the availability mechanism is operationalized by boundary spanners' peripheral position and interorganisational mobility, as well as by their 
information and network management skills. The latter enable them to tap into alternative pools of information, which they use strategically to pursue their interests and to instigate change.

\subsubsection{Accessibility}

Accessibility refers to the knowledge and information that comes to mind (Thornton et al., 2012). Individuals who are embedded in one institutional logic are likely to invoke knowledge that is part of that logic. Once the knowledge associated with this logic becomes widely shared among members of a group, it becomes readily accessible or taken for granted, and provides cognitive shortcuts for actors to make sense of reality (Hong and Mallorie, 2004). When these members are confronted with an alternative logic, their cognitive shortcuts can be in conflict (Thornton et al., 2012). The new logic then needs to be re-interpreted, so that its rationality becomes evident. Boundary spanners achieve this by virtue of being T-shaped professionals (experts in a specific area, with a broad working knowledge of other areas), which means they are attuned to the social construction and information coding schemes of actors with different backgrounds (Meerkerk et al., 2014; Tushman and Scanlan, 1981). They can bridge different ways of understanding by skilfully recoding information in a way that suits the receiver (Organ, 1971). This 'cognitive filtering' through verbal, non-verbal, or written actions helps others to interpret a new logic (Williams, 2012). They are knowledgeable and skilled in using discipline-specific language, cues, or customs, and they utilize different communication tools to mediate between different meaning systems. They thereby connect new cognitive shortcuts with familiar interpretations of reality, to make alternative institutional logics accessible to other actors.

\subsubsection{Activation}

Activation refers to whether or not available and accessible knowledge and information are actually used in social interaction (Thornton et al., 2012). Activation is a function of the second mechanism, accessibility, and focus of attention: attention triggers the activation of accessible knowledge structures. In standard and routine situations the focus of attention is automatic, triggering readily accessible knowledge and routine behaviour. But when actors are confronted with new situations, the focus shifts from automatic to more controlled forms of attention that stimulate freedom of thought and action (Ocasio, 2010; Thornton et al., 2012). Boundary spanners can operationalize this activation mechanism in two ways. First, they steer attention into a desired direction by customising behaviour and action schemas. These are mental codifications of perceptions and experiences that determine what problems and issues get attended to, and what solutions are likely to be considered. Different logics provide different behaviour and action schemas that guide the focus of attention. Boundary spanners' peripheral position and inter-organizational mobility allow them to access different schemas, and to apply them in specific situations to steer other actors' attention toward specific problems, actions, and solution. Environmental stimuli also influence attention, and can be amplified by boundary spanners through use of rhetorical strategies. These lend themselves to dual ends: not just mediation (to harmonize relationships) but also provocation (to foster contention and dispute), which intensifies the salience of an environmental stimulus by influencing other actors' perception of an event. Both uses of rhetorical strategies channel attention in a desired direction to activate alternative institutional logics.

\section{Methodology}

To investigate structure and agency in a system innovation through a boundary spanning and institutional logics lens, this paper uses a single embedded case study design (Eisenhardt, 1989; Yin, 2009). Melbourne's urban stormwater management system changed profoundly from 1960 - 2015 which is the time period under investigation for this longitudinal research (see Brown and Clark, 2007; Brown et al., 2013; Ferguson et al., 2013).

Transcripts of oral histories, group interviews, and individual interviews from previous research (as collected and used by Brown et al., 2013) were reanalysed for the purpose of this study. We followed an inductive, open ended data analysis in which we moved back and forth between data, literature on BS / IL and emerging theory. We gradually abstracted from the raw data by linking concepts to emerging themes through which we developed our theoretical framework (Locke, 2001). This iterative process was supplemented by secondary data (historical and contemporary) drawn from scientific literature, policy materials, media campaigns (e.g. newspapers), organizational literature, and reports of industry associations and government agencies.

Water Sensitive Urban Design (WSUD), an umbrella term for an alternative stormwater management practice, represents the socio-technical artefact of this change trajectory. WSUD's widespread, irreversible, and systemic adoption in policy and on-ground practice renders changes in the urban stormwater management system transitional (Brown et al., 2013). Importantly, actors were pivotal in navigating the up-scaling of WSUD and the associated institutional change processes (Ferguson et al., 2014), which makes Melbourne a worthy case for analysis. In refining the framework with the case application, we are using ideal typical IL in the field of urban 
water management (see Fuenfschilling \& Truffer, 2014) to trace the IL in the field of stormwater management, which boundary spanners operated with in Melbourne.

To complement our analysis we investigated the content of the dominant advocating narrative, asking if and how it changed over the course of the system innovation. Narratives signify both stability and change in the institutional environment (Phillips et al., 2004). They are considered key actor strategies but also qualitative indicators of institutional transformation in systemic change processes (Smith \& Raven, 2012; Zietsma \& Lawrence, 2010). The transition phases reported by Brown et al. (2013) were adapted and used to map phase-distinct change processes, and to construct a compelling case description.

\section{Case Study Results}

Metropolitan Melbourne is Australia's second-largest capital city located around a large natural bay. The receiving aquatic environment is highly diverse, and the area shows an extensive network of rivers, creeks, and wetlands. Similar to other systems (see Scott et al., 2000, for health care), urban stormwater management in Melbourne is characterized by institutional complexity. Fuenfschilling and Truffer (2014) identified three different types of institutional logics which structure urban water management systems in Australia. While the ideal types developed by Fuenfschilling and Truffer offer a helpful typology of institutional logics in urban water management, we have adapted the last column in Table 3 based on current scientific, political, and public thinking and discourse about a Water Sensitive Logic (WSL) as used in Melbourne.

Table 3. Ideal types of organizational field logics of urban stormwater management in Melbourne. Adapted from Fuenfschilling and Truffer (2014)

\begin{tabular}{|c|c|c|c|}
\hline $\begin{array}{l}\text { Institutional logic } \\
\text { elements }\end{array}$ & Hydraulic Logic (HL) & Water Market Logic (WML) & Water Sensitive Logic (WSL) \\
\hline Values & $\begin{array}{l}\text { Security of supply, national welfare, social } \\
\text { equity }\end{array}$ & $\begin{array}{l}\text { Economic efficiency, } \\
\text { rationalization }\end{array}$ & Equity, resilience \\
\hline Mission & Irrigation, consumption, electricity & Water markets & Integrated water cycle management \\
\hline Technology & Dams & Most cost-effective technology & Fit for purpose, hybrid technology \\
\hline Main actors & Utility engineers, public authorities & Consultants, economists, market & $\begin{array}{l}\text { All relevant field actors across } \\
\text { disciplines }\end{array}$ \\
\hline Expertise & Technical & Economic & Transdisciplinary \\
\hline Organizational form & Vertically integrated state-owned utility & Private firm & Multi-sector/organization \\
\hline Funding & Government & Consumer & Government and consumer \\
\hline
\end{tabular}

Equipped with this typology, we can analyze the story of Melbourne's urban stormwater management transformation, and highlight key events that indicate shifts in the relationship between logic constellations, boundary spanning and corresponding niche and regime developments.

\subsection{Pre-development (pre-1960s): Figure 2}

The institutional legacy of the Melbourne urban stormwater management field goes back to the first European settlements in the mid-1800s (Cathcart, 2009; Colebatch, 2006). No alternative logics were available and the field was institutionally homogenous. The regime was also institutionally homogenous, resting purely on the foundations of the Hydraulic Logic (HL). Given the historical length of this initial phase, the logic elements (see Table 3) had plenty of time to align with each other and became highly coherent internally. Stormwater management was characterized by centralized, highly engineered infrastructure and a top-down 'predict and control' approach that was executed by hydraulic engineers who dominated powerful state-owned utilities. The regime was unchallenged, because the absence of alternative logics diminished niche developments, increased stability, and fortified the status quo. Attention was channelled toward readily available behaviour and action schemas, leading to the continuous reproduction of logic-conforming behaviour and practices that confined innovation along narrow trajectories. Agency was habitual, and boundary spanning was absent.

\subsection{Seeds of Change (1960s-1989): Figure 3}

The period from the 1960s to the late-1980s was characterized by socio-technical landscape shifts which spawned the emergence of alternative institutional logics in the field. Similar to other organizational fields (e.g. publishing, see Thornton and Ocasio, 1999), the rise of neoliberalism became refracted in the urban stormwater management field (Byrnes, 2013), establishing the antecedence for a Water Market Logic (WML). In a similar vein, the global 
rise of environmentalism allowed a Water Sensitive Logic (WSL) to emerge While the regime remained institutionally homogenous in this phase, the Hydraulic Logic was no longer the sole source of rationality, and the system as a whole began to be challenged. Boundary spanning activities started to pick up environmental protectionist ideas and applied them to the Melbourne water management context, which spawned a Water Sensitive Logic. Boundary spanners highlighted the deterioration of Melbourne's receiving waterways and linked these problems to current approaches of urban stormwater management. This lead to the first environmental assessment studies of Melbourne's waterways, ignited new community initiatives and professional training workshops, and nurtured an emerging knowledge base. The advocating narrative gravitated around waterway health and peaked in the successful newspaper campaign, "Give the Yarra [River] a Go!", which led to the redirection of political and financial resources to protect Melbourne's receiving aquatic environment.

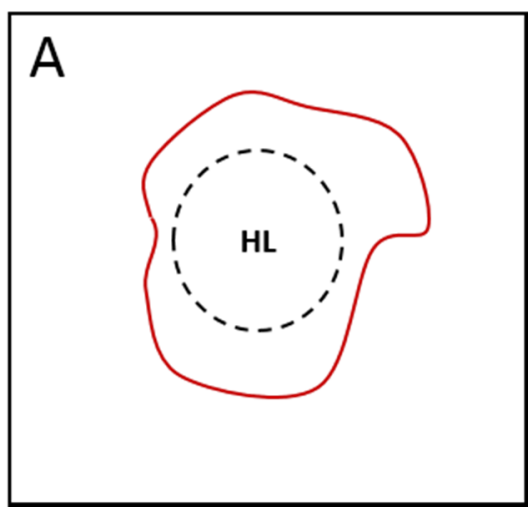

Figure 2. Pre-development (pre-1960s); Phase A

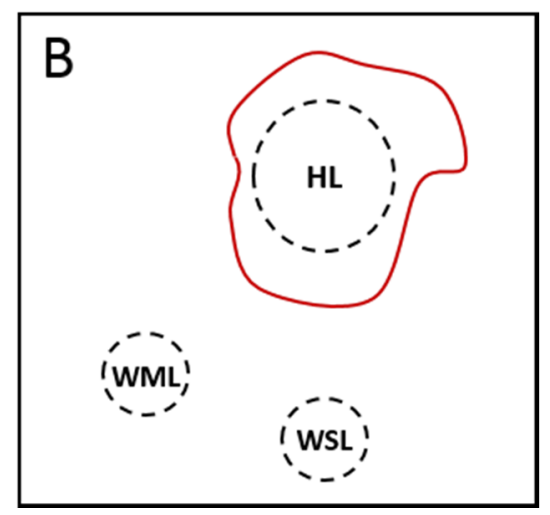

Figure 3. Seeds of change (1960s-1989); Phase B

\subsection{Niche Emergence and Formation (1990-1999): Figure 4}

The Water Market and the Water Sensitive Logic started to solidify in this period. The elements of the Water Market Logic were more aligned with the Hydraulic Logic of the regime. This led to an internalization of the Water Market Logic and increased the institutional heterogeneity of the regime. In contrast, the Water Sensitive Logic dictates fundamentally different stormwater management practices that challenged the regime, providing the antecedents for niche development in this phase. The Water Sensitive Urban Design (WSUD) niche, with a strong stormwater quality focus, was able to form because of the institutional capacity of the Water Sensitive Logic. Subsequently, elements of the WSL became slowly institutionalized in the field and became increasingly coherent. Institutional logic elements such as value, mission, and technology (see Table 3) found increasing uptake in policy making and planning, which formalized their existence. For example, new science-based policy targets of nitrogen, phosphorus, and suspended solid reduction became established, as did legally binding water quality and drainage targets on development permits.

In this period boundary spanners utilized the new institutional working space provided by the logic to facilitate niche emergence and formation. On the one hand, boundary spanners sought to strengthen the Water Sensitive Logic by providing scientific evidence of innovative stormwater treatment technologies to industry and policy makers. This strengthening of WSL elements (e.g., technology or expertise) made the logic increasingly available to others while fostering accessibility of these elements through science-industry partnerships. On the other hand boundary spanners opportunistically utilized the material provided by the Water Market Logic to pursue their goals. For example, a boundary spanner at Melbourne Water (a local utility) actively encouraged land developers to incorporate WSUD into their developments in order to achieve market differentiation and financial benefits. Elements of the Water Sensitive Logic (technology: WSUD) were thereby made accessible through their reframing with elements of the Water Market Logic (values: economic efficiency rationale). Similarly, another boundary spanner in the same organization negotiated a deal to take on the financial risks for a local municipality if water sensitive infrastructure was to fail in a large development project. Elements of the Hydraulic Logic (mission and values: the state as a protector of water safety) were used to achieve a better institutional fit of the project in the decision-making process with incumbents. A Water Sensitive Logic was thus made more accessible through the transposition of Hydraulic Logic elements to a water sensitive project. This strategy turned out to be 
successful, and the construction of the focus projects led to an increasing institutionalization of WSL elements, and to the up-scaling of the WSUD niche in subsequent phases.

The advocating narrative shifted from the previous period's focus on the problem or cause to potential solutions, highlighting that 'end-of-pipe' technologies were not appropriate, and that source control and non-structural measures should be taken up.

\subsection{Niche expansion and Translation (2000-2010): Figure 5}

The Water Sensitive Logic strengthened in this period through an increasing institutionalization of WSL elements and their growing internal coherence. This fostered niche developments and niche expansion, as shown by an increasing number of on-the-ground WSUD projects, as well as significant regulatory and policy changes. For example, Melbourne hosted the first WSUD conference in order to bring together practitioners, policy makers, and researchers. The conference attracted 170 participants, signifying rising acceptance of the WSUD approach by practitioners in the field. Secondly, the 'clean stormwater - a planning framework' project was initiated by a local council and Melbourne water with the aim of identifying statutory planning mechanisms to mandate WSUD in redevelopment and new development sites. Thirdly, a capacity building organization, 'Clearwater', was established to train stormwater professionals on the technical and philosophical benefits of WSUD practices. Fourthly, the first formal multi-level, inter-agency stormwater policy network of senior decision-makers was established, exemplifying buy-in of industry leaders in the field.

At this time the millennium drought peaked in Australia, severely compromising Melbourne's water supply. State resources became increasingly directed at traditional regime practices, with public and political attention shifting back to a narrower water supply focus that strongly invigorated the Hydraulic Logic. However, boundary spanners were quick to respond to the changing context and reframed their water sensitive agenda with elements from the Hydraulic Logic. When promoting WSUD, they now emphasized the benefits of water supply through stormwater harvesting, claiming that this was a missing and critical source to assure supply security. Opportunistically, boundary spanners thereby transposed elements of a Hydraulic Logic (mission: supply security), redirecting the focus of attention toward new benefits with the aim to activate the Water Sensitive Logic. Logic activation is also exemplified by Melbourne Water's 'Stormwater Quality Offset Strategy', which puts prices on nutrient loads of stormwater runoff - a crucial financial incentive to channel attention to stormwater mitigation strategies for land developers in order to facilitate WSUD uptake. Together, these events and processes highlight the growing strength of the WSUD niche and its underpinning Water Sensitive Logic.

The narrative during this phase was influenced by the drought and the repositioning of WSUD as water supply innovation. 'Cities as water supply catchments' became the motto of this new narrative.

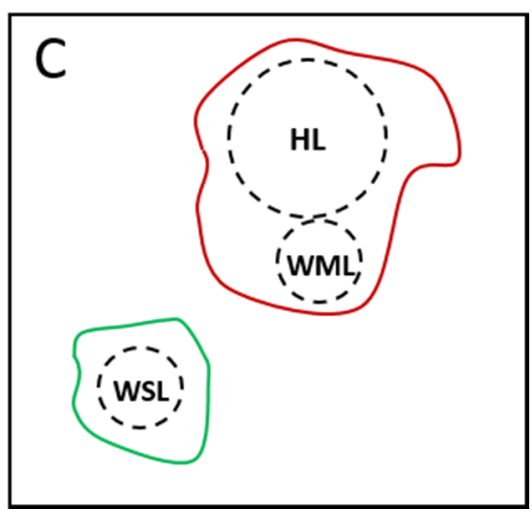

Figure 4. Niche emergence and formation (19901999); Phase C

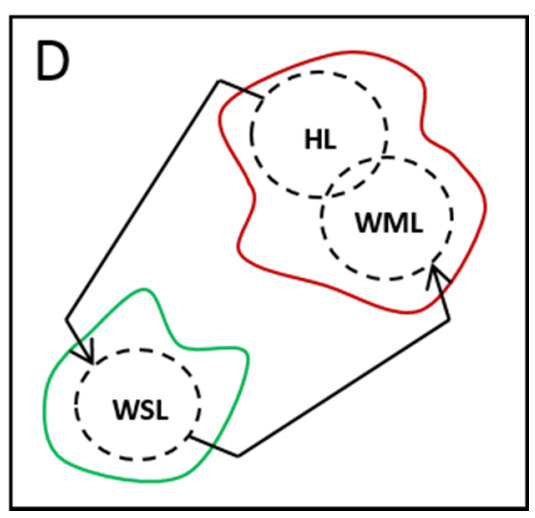

Figure 5. Niche expansion and translation (2000-

2010); Phase D

\section{5 (Pre-)Stabilization (2011 onward): Figure 6}

Since 2011, the urban stormwater management field in Melbourne has been characterized by three equally strong institutional logics that jointly structure the field. The niche has adapted to the operational reality and incorporated elements of the Hydraulic and Market Logic. In a similar vein the regime has adapted to the niche, embracing 
symbolic and material elements of the WSL in its day-to-day business. Policy shifts, widespread adoption of water sensitive practices, and new research directions suggest that the niche has come to a (pre-)stabilization period (Figures 6 and 7, Phase E). Key boundary spanners from the previous periods now occupy executive positions and directly advise the state water minister. Their executive position and legitimacy allows them to activate the Water Sensitive Logic, and to further expand the niche to the point where WSUD is an unquestioned consideration in the urban stormwater decision-making process. In our Melbourne example, these senior boundary spanners' recommendations to the state government drove the establishment of the Office of Living Victoria, with the mission to transform water cycle management in Melbourne, and to understand how water cycle services are provided allocating another 70 million Australian dollars for WSUD projects in the Melbourne region. Additionally, they successfully advocated for the establishment of the Cooperative Research Centre (CRC) for Water Sensitive Cities (an umbrella organization for science-industry partnerships to support research collaborations between industry and end-users). Melbourne was chosen as the permanent headquarter of this CRC, and a budget of AU\$100 million was allocated for the CRC to guide capital investments of the water sector over the next 15 years. Indicative of this period is a broader narrative relating to prosperity and environmental liveability, appealing to the desire of all stakeholders to make Melbourne a world-leading city.

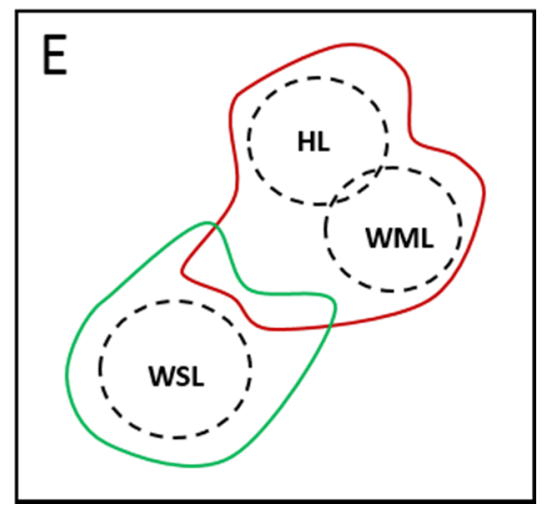

Figure 6. (Pre-)Stabilization (2011 onwards); Phase E

\section{Discussion}

Understanding the socio-institutional pattern that opens up previously locked-in pathways in different domains of change (technological, cultural, political, etc.) is critical if we want to advance our understanding of sustainability transitions and successfully navigate their pathway. This study investigated the practical dynamics of structure and agency in a particular system innovation through an institutional logics and boundary spanning lens. We identified relationship patterns between dominant forms of boundary spanning and institutional logics, from which we draw important insights for the advancement of transitions theory.

We found that early stages of a system innovation are characterized by the domination of a single institutional logic. Its elements are highly coherent and institutionalized, providing the sole source of rationality. At this stage, deviation from the predominant rule set is unlikely, leading to the constant reproduction of taken-for-granted behaviour and practices with limited capacity for change (Figure 7, Phase A). In Melbourne, this situation was reflected by the previously unchallenged domination of a hydrologic engineering dogma in which a command-and-control approach led to the unquestioned construction of large scale, centralized, and highly engineered infrastructure. This approach is characteristic of an institutional homogeneity observed in urban water management worldwide (e.g. Molle et al., 2009; Söderholm, 2013). We found that while broader societal trends may exist outside of a field, it needs strategic efforts of key individuals to introduce these trends into an institutionally homogenous and highly stable system. This stage requires boundary spanning focused on making available alternative institutional logics to others. When successful, this form of boundary spanning activity facilitates growth of alternative institutional logics, increasing the system's complexity and encouraging 'recognition' between logics (Figure 7, Phase B). Our Melbourne case exemplifies this process via the continuous introduction of environmental protectionist ideas and values to the stormwater management field by an informal network of loosely connected key individuals from multiple sectors. This 'introductory' institutional groundwork in highly stable fields has also been observed in the car industry (Penna and Geels, 2012) and in agriculture (Elzen 
et al., 2011). It sets up subsequent niche development processes which, in our case, led to the establishment of an alternative stormwater management practice. The advocating narrative of this development stage articulates the system's problems and their cause, reflecting a growing recognition of, and engagement with, socio-technical landscape developments. "Give the Yarra A Go!" was the motto for this narrative in Melbourne, which used one of the city's most iconic waterways to raise environmental awareness and alert people to the urban water management problem.
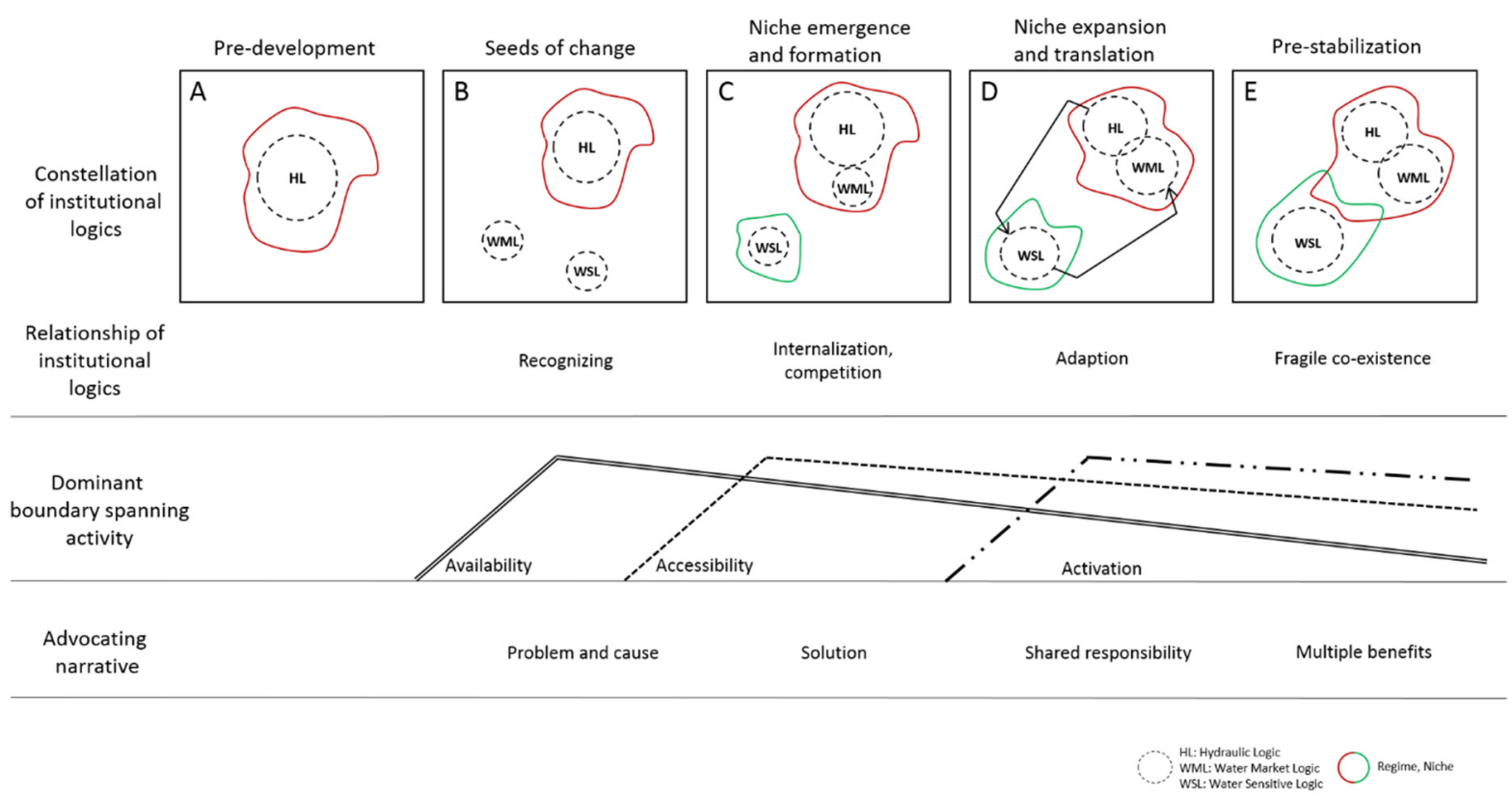

Figure 7. The co-evolution between Institutional logics, dominant forms of boundary spanning, and corresponding niche and regime developments in the urban stormwater management field of Melbourne,

Australia

Once broader societal trends are remodelled in a sector-specific field logic, other actors have the possibility to tap into alternative rationalities, allowing them to explore new but increasingly legitimized ways of thinking and doing (Figure 7, Phase C). This new institutional space serves as a springboard for a diverse array of alternative industry practices (e.g. Rao et al., 2003; Thornton et al., 2005). In Melbourne this led to the emergence of a niche practice (WSUD), which was supported by the increasing legitimacy of the solidifying Water Sensitive Logic through a growing number of its proponents. The increasing strength of a challenger logic and corresponding niche developments are likely to fuel competition with the old regime logic and incumbents. However, conflict between logics is only one option, as alternative logics can also be internalized by the regime if their elements are sufficiently aligned. We found that the regime internalized the Water Market Logic due to its match with the established Hydraulic Logic. From a niche perspective boundary spanning activities focused on accessibility to mediate the new logic material, making it easier to implement within the regime-driven decision-making culture. This type of boundary spanning facilitates niche expansion and consolidation which, in turn, increases the strength of the underpinning institutional logics. Our case exemplified this development through its reframing of WSUD projects with elements of the well-established and widely recognized regime logic in order to sell it to incumbents. This reframing of an alternative practice has also been revealed in other contexts as an effective strategy to enhance logic conformity (e.g. Christiansen and Lounsbury, 2013; Rao and Giorgi, 2006). The advocating narrative then shifts to the next stage and focuses on portraying niche innovation, promotion of alternative solutions, and challenging of established regime practices. From an agency perspective, this indicates an important strategic intent: to argue for niche-empowering institutional reform (Smith and Raven, 2012). In Melbourne, this narrative was shaped by the showcasing of successful focus projects and a crystallizing vision of water sensitivity in the urban context.

In later stages, boundary spanners don't stop using the principles of availability and accessibility, but the niche logic's growing strength allows for more vigorous, agency-led processes to gain momentum. At this stage 
boundary spanning activities start to focus on the activation of alternative institutional logics. Boundary spanners potentially occupy more senior positions, allowing them to force niche and regime logics into exchange and adaption. In Melbourne, powerful boundary spanners enabled the implementation of statutory measures on the basis of water sensitive ideas, with which incumbents had to comply. This is indicative of advanced stages of a system innovation, which can also be observed in Germany's energy system (Hoppmann et al., 2014). Moreover, boundary spanners opportunistically used the public's concern about Australia's severe drought to direct attention to the alternative benefits of stormwater harvesting: supply security, in addition to stormwater quality treatment with WSUD. By redirecting the focus of attention, the boundary spanners triggered activation at a time when an institutional backlash was looming, and leveraged resources to strengthen WSL elements and associated WSUD practices. This lead to niche expansion and the translation of niche-regime practices on a large scale, beyond experimentation and piloting projects (Figure 7, Phase D). The advocating narrative at this stage echoed the adaption process of institutional logics, and in our Melbourne case underlined the shared responsibilities of all players in the system, linking established with new ways of doing.

In the (pre-)stabilization phase a field has been restructured, while the logic constellation has matured and different logics jointly influence the system. Old and new practices have adapted to each other, and both play a distinctive role in day-to-day operations. What might look like a new equilibrium in the system is more likely to be of a fragile nature: an 'uneasy truce' (Reay and Hinings, 2009) between a newly established niche logic and the traditional regime logic. In Melbourne WSUD and its institutional foundation are now integral to urban stormwater management, but old and new practices continue to coexist. This requires constant boundary spanning agency in response to new developments, with the aim to uphold and strengthen the influence of the new logic, and to tilt the balance in its favour. However, boundary spanning agency is more likely to have a collaborative pitch given the coexistence of old and new logics in the system, and the pragmatic working relationships of actors (Reay and Hinings, 2009). The message of the advocating narrative widens by emphasising multiple benefits of the niche to address the highest possible number of stakeholders. The narrative became distinctly non-technical in Melbourne, highlighting the concept of liveability, and appealing to a desire for increased prosperity. The current presence of the Water Sensitive Logic in the dominant discourse weakened the regime narrative underpinned by HL and WML reasoning, and indicates an advanced phase of a system innovation (Bosman et al., 2014).

Finally, we point at the limitations of this study and suggest future research directions. While the wealth of primary and secondary data of our case provided important descriptive detail to investigate IL and BS in this system innovation, the data was primarily collected for a different research aim. This limits a broader analysis of agency from a regime perspective, and of the question how incumbents utilize elements of a challenger logic to shield existing practices and to fortify the status quo. Moreover, we want to highlight that this case describes a particular trajectory in which individuals drove the successful institutionalization of a radical innovation. While this provides crucial insight into the nature and timing of successful boundary spanning, other, less successful pathways should also be explored. This would contribute to a richer understanding of how structure and agency co-evolve in a backlash or on another, less desirable pathway. Additionally, it would be important to empirically assess how elements of logics change over time in order to reveal modifications of the institutional material with which boundary spanners operate, and the adaptive relationship between niches and regimes.

\section{Conclusion}

This study investigated the co-evolution of structure and agency over the course of a system innovation through an institutional logics and boundary spanning lens. Our contribution to sustainability transitions research is twofold. First, the explanatory power of institutional and agency theory enabled us to provide a deeper understanding of core issues in sustainability transitions research: inertia and practice change in socio-technical systems. Simultaneously looking at structure and agency in a longitudinal analysis of system innovation allowed us to reveal the socio-institutional pattern that describes the breakthrough, diffusion, and up-scaling of a radical innovation in the face of competing and conventional practices. This pattern is best described as a co-evolutionary relationship in which the interplay between both dimensions determined how this trajectory unfolded. Figure 7 illustrates this pattern and highlights turning points in logic constellations and dominant forms of boundary spanning. This can be used as a tool by transition analysts to benchmark the stage of a system innovation against socio-institutional parameters that signify the extent to which an alternative practice is institutionalized. Our second contribution concerns the topic of agency in sustainability transitions. Even though a co-evolutionary perspective is paramount in explaining the success of this system innovation, our study suggests there is leverage in using certain types of boundary spanning at certain transition phases. While all forms of boundary spanning were required for the successful institutionalization of a radical innovation, different forms of boundary spanning seem to be more fruitful when well matched with the dominant relationship of institutional logics. This suggests 
that performing the right type of boundary spanning agency at the right time can be pivotal in strengthening the institutional foundations that support the growth of a niche. This study therefore provides a new perspective on transformative change agency, which takes the social and material dimensions of niches and regimes into account, and which is positioned along the entire developmental arc, rather than at a specific phase, of a system innovation.

\section{Acknowledgements}

We gratefully acknowledge the support of the Commonwealth of Australia through the Cooperative Research Centre Program. We also thank the Australian Research Council for providing support (DP120102791) for this research.

\section{References}

Bosman, R., Loorbach, D., Frantzeskaki, N., \& Pistorius, T. (2014). Discursive regime dynamics in the Dutch energy transition. Environmental Innovation and Societal Transitions, 13, 45-59. https://doi.org/10.1016/j.eist.2014.07.003

Bourdieu, P. (1977). Outline of a Theory of Practise. Cambridge University Press, Cambridge, UK. https://doi.org/10.1017/CBO9780511812507

Bressers, H., \& Lulofs, K. (2010). Governance and Complexity in Water Management - Creating Cooperation through Boundary Spanning Strategies. Edward Elgar Publishing, Cheltham, UK.

Brown, R. R., Farrelly, M. A., \& Loorbach, D. A. (2013). Actors working the institutions in sustainability transitions: The case of Melbourne's stormwater management. Global Environmental Change, 23, 701-718. https://doi.org/10.1016/j.gloenvcha.2013.02.013

Brown, R., \& Clark, J. (2007). Transition to Water Sensitive Urban Design: The story of Melbourne, Australia, Report No. 7 (1), Facility for Advancing Water Biofiltration. Monash University.

Bryson, J. M., \& Crosby, B. C. (2006). The Design and Implementation of Cross-Sector Collaborations: Propositions from the Literature. Public Administration Review, 66, 45-55. https://doi.org/10.1111/j.1540-6210.2006.00665.x

Byrnes, J. (2013). A short institutional and regulatory history of the Australian urban water sector. Utilities Policy, 24, 11-19. https://doi.org/10.1016/j.jup.2012.09.001

Cathcart, M. (2009). The Water Dreamers. The Remarkable History of Our Dry Continent. The Text Publishing Company, Melbourne, Australia.

Christiansen, L., \& Lounsbury, M. (2013). Strange Brew: Bridging logics via institutional bricolage and the reconstitution of organizational identity. Institutional Logics in Action, Part B, 39(2013), 199-232.

Colebatch, H. K. (2006). Governing the use of water: the institutional context. Desalination, 187(1), 17-27. https://doi.org/10.1016/j.desal.2005.04.064

Daudigeos, T., Boutinot, A., \& Jaumier, S. (2013). Taking Stock of Institutional Complexity: Anchoring a Pool of Institutional Logics into the Interinstitutional System with a Descendent Hierachical Analysis. Research in the Sociology of Organizations A, (39), 319-350.

De Haan, J., \& Rotmans, J. (2011). Patterns in transitions: Understanding complex chains of change. Technological Forecasting and Social Change, 78(1), 90-102. https://doi.org/10.1016/j.techfore.2010.10. 008

Dolata, U. (2013). The Transformative Capacity of New technologies. A Theory of Sociotechnical Change. Routledge, New York, USA.

Edelenbos, J., Van Buuren, A., \& Klijn, E.-H. (2013). Connective Capacities of Network Managers. Public Management Review, 15(1), 131-159. https://doi.org/10.1080/14719037.2012.691009

Eisenhardt, K. M. (1989). Building Theories from Case Study Research. The Academy of Management Review, 14(4), 532.

Elzen, B., Geels, F. W., Leeuwis, C., \& van Mierlo, B. (2011). Normative contestation in transitions "in the making": Animal welfare concerns and system innovation in pig husbandry. Research Policy, 40(2), 263275. https://doi.org/10.1016/j.respol.2010.09.018

Elzen, B., van Mierlo, B., \& Leeuwis, C. (2012). Anchoring of innovations: Assessing Dutch efforts to harvest energy from glasshouses. Environmental Innovation and Societal Transitions, 5, 1-18. https://doi.org/10. 1016/j.eist.2012.10.006 
Farla, J., Markard, J., Raven, R., \& Coenen, L. (2012). Sustainability transitions in the making: A closer look at actors, strategies and resources. Technological Forecasting and Social Change, 79(6), 991-998. https://doi.org/10.1016/j.techfore.2012.02.001

Ferguson, B. C., Brown, R. R., Frantzeskaki, N., de Haan, F. J., \& Deletic, A. (2013). The enabling institutional context for integrated water management: lessons from Melbourne. Water Research, 47(20), 7300-7314. https://doi.org/10.1016/j.watres.2013.09.045

Ferguson, B., Brown, R., de Haan, F., \& Deletic, A. (2014). Analysis of institutional work in innovation trajectories in water infrastructure systems of Melbourne, Australia. Environmental Innovation and Societal Transitions, (15), 42-64.

Fuenfschilling, L., \& Truffer, B. (2014). The structuration of socio-technical regimes - Conceptual foundations from institutional theory. Research Policy, 43(4), 772-791. https://doi.org/10.1016/j.respol.2013.10.010

Geels, F. W. (2004). From sectoral systems of innovation to socio-technical systems insights about dynamics and change from sociology and institutional theory. Research Policy, 33(6), 897-920. https://doi.org/10.1016/j.respol.2004.01.015

Geels, F., Kemp, R., Dudley, G., \& Lyons, G. (Eds.) (2011). Automobility in Transition? A Socio-technical Analysis of Sustainable Transport.Routledge, New York, USA.

Giddens, A. (1984). The Constitution of Society. University of California Press, Berkley and Los Angeles.

Goodrick, E., \& Reay, T. (2011). Constellations of Institutional Logics: Changes in the Professional Work of Pharmacists. Work and Occupations, 38(3), 372-416. https://doi.org/10.1177/0730888411406824

Grin, J., Rotmans, J., \& Schot, J. (2010). Transitions to Sustainable Development. Routledge, New York, USA.

Hong, Y., \& Mallorie, L. M. (2004). A dynamic constructivist approach to culture: Lessons learned from personality psychology. Journal of Research in Personality, 38(1), 59-67. https://doi.org/10.1016/j.jrp.2003.09.003

Hoogman, R., Kemp, R., Schot, J., \& Truffer, B. (2002). Experimenting for Sustainable Transport. The approach of Strategic Niche Management. Spon Press, London, UK.

Hoppmann, J., Huenteler, J., \& Girod, B. (2014). Compulsive policy-making - The evolution of the German feed-in tariff system for solar photovoltaic power. Research Policy, 43(8), $1422-1441$. https://doi.org/10.1016/j.respol.2014.01.014

Huitema, D., \& Meijerink, S. (2010). Realizing water transitions: the role of policy entrepreneurs in water. Ecology and Society, 15(2), 26. https://doi.org/10.5751/ES-03488-150226

Kemp, R., Rip, A., \& Schot, J. (2001). Constructing transition paths through the management of niches. In R. Garud, \& P. Karnoe (Eds.), Path dependence and creation (pp. 269-299). Lawrence Erlbaum, London, UK.

Kemp, R., Schot, J., \& Hoogma, R. (1998). Regime Shifts to Sustainability Through Processes of Niche Formation: The Approach of Strategic Niche Management. Technology Analysis and Strategic Management, 10(2), 175 - 195. https://doi.org/10.1080/09537329808524310

Kivisaari, S., Saari, E., Lehto, J., Kokkinen, L., \& Saranummi, N. (2013). System innovations in the making: hybrid actors and the challenge of up-scaling. Technology Analysis \& Strategic Management, 25(2), $187-201$. https://doi.org/10.1080/09537325.2012.759202

Langan-Fox, J., \& Cooper, C. (Eds.) (2014). Boundary Spanning in Organizations. Routledge, New York, USA.

Loorbach, D. (2010). Transition Management for Sustainable Development: A Prescriptive, Complexity-Based Governance Framework. Governance, 23(1), 161-183. https://doi.org/10.1111/j.1468-0491.2009.01471.x

Loorbach, D., \& \& Rotmans, J. (2010). The practice of transition management: Examples and lessons from four distinct cases. Futures, 42(3), 237-246. ttps://doi.org/10.1016/j.futures.2009.11.009

Markard, J., Raven, R., \& Truffer, B. (2012). Sustainability transitions: An emerging field of research and its prospects. Research Policy, 41(6), 955-967. https://doi.org/10.1016/j.respol.2012.02.013

Meerkerk, I. Van, Edelenbos, J., \& Klijn, E. (2014). Connective Management and Governance Network Performance: the mediating role of Throughput Legitimacy. Findings from survey research on complex water projects in the Netherlands. Environment and Planning C: Government and Policy, 32, 1-19. 
Meerkerk, I., \& Edelenbos, J. (2013). The effects of boundary spanners on trust and performance of urban governance networks: findings from survey research on urban development projects in the Netherlands. Policy Sciences, 47(1), 3-24. https://doi.org/10.1007/s11077-013-9181-2

Molle, F., Mollinga, P. P., \& Wester, P. (2009). Hydraulic Bureaucracies and the Hydraulic Mission: Flows of Water. Flows of Power, 2(3), 328-349.

Ocasio, W. (2010). Attention to Attention. Organization Science, 22(5), 1286-1296. https://doi.org/10.1287/ orsc. 1100.0602

Organ, D. W. (1971). Linking Pins between Organizations and Environment: Individuals do the interacting. Business Horizons, 14(6), 73-80. https://doi.org/10.1016/0007-6813(71)90062-0

Pache, A., \& Santos, F. (2013). Embedded in Hybrid Contexts: How Individuals in Organizations Respond to Competing Institutional Logics. In M. Lounsbury, \& E. Boxenbaum (Eds.), Institutional Logics in Action, Part B (Research in the Sociology of Organizations, Volume 39, Part B, pp. 3-35). Emerald Group Publishing Limited.

Pahl-Wostl, C. (2006). Transitions towards adaptive management of water facing climate and global change. Water Resources Management, 21(1), 49-62. https://doi.org/10.1007/s11269-006-9040-4

Penna, C. C. R., \& Geels, F. W. (2012). Multi-dimensional struggles in the greening of industry: A dialectic issue lifecycle model and case study. Technological Forecasting and Social Change, 79(6), 999-1020. https://doi.org/10.1016/j.techfore.2011.09.006

Phillips, N., Lawrence, T., \& Hardy, C. (2004). Discourse and institutions. Academy of Management Review, 29(4), 635-652.

Rao, H., \& Giorgi, S. (2006). Code Breaking: How Entrepreneurs Exploit Cultural Logics to Generate Institutional Change. Research in Organizational Behavior, 27(6), 269-304. https://doi.org/10.1016/S0191-3085(06) 27007-2

Rao, H., Monin, P., \& Durand, R. (2003). Institutional Change in Toque Ville: Nouvelle Cuisine as an Identity Movement in French Gastronomy. American Journal of Sociology, 108(4), 795-843. https://doi.org/10.1086/ 367917

Reay, T., \& Hinings, C. R. (2009). Managing the Rivalry of Competing Institutional Logics. Organization Studies, 30(6), 629-652. https://doi.org/10.1177/0170840609104803

Rip, A., \& Kemp, R. (1998). Technological Change. In S. Rayner, \& E. L. Malone (Eds.), Human Choice and Climate Change - Resources and Technology (pp. 327-399). Battelle Press, Columbus.

Rotmans, J., Kemp, R., \& Van Asselt, M. (2001). More evolution than revolution: transition management in public policy. Foresight, 3(1), 15-31. https://doi.org/10.1108/14636680110803003

Scott, R., Ruef, A., Mendel, P., \& Caronna, C. (2000). Institutional Change and Healthcare Organizations. From Professional Dominance to Managed Care. University of Chicago Press, Chicago, USA.

Smink, M., Negro, S. O., Niesten, E., \& Hekkert, M. P. (2015). How mismatching institutional logics hinder niche-regime interaction and how boundary spanners intervene. Technological Forecasting and Social Change. https://doi.org/10.1016/j.techfore.2015.07.004

Smith, A., \& Raven, R. (2012). What is protective space? Reconsidering niches in transitions to sustainability. Research Policy, 41(6), 1025-1036. https://doi.org/10.1016/j.respol.2011.12.012

Smith, A., Stirling, A., \& Berkhout, F. (2005). The governance of sustainable socio-technical transitions. Research Policy, 34(10), 1491-1510. https://doi.org/10.1016/j.respol.2005.07.005

Söderholm, K. (2013). Governing socio-technical transitions: Historical lessons from the implementation of centralized water and sewer systems in Northern Sweden, 1900-1950. Environmental Innovation and Societal Transitions, 7, 37-52. https://doi.org/10.1016/j.eist.2013.03.001

Spaargaren, G., Oosterveer, P., \& Loeber, A. (Eds.) (2012). Food Practices in Transition. Routledge, New York, USA.

Steadman, H. J. (1992). Boundary Spanners: A Key Component for the Effective Interactions of the Justice and Mental Health Systems. Law and Human Behavior, 16(1), 75-87. https://doi.org/10.1007/BF02351050 
Thornton, P., \& Ocasio, W. (1999). Institutional Logics and the Historical Contingency of Power in Organizations: Executive Succession in the Higher Education Publishing Industry, 1958 - 1990. American Journal of Sociology, 105(3), 801-843. https://doi.org/10.1086/210361

Thornton, P., Jones, C., \& Kury, K. (2005). Institutional logics and institutional change in organizations: Transformation in accounting, architecture, and publishing. Resear in the Sociology of Organizations, 23(05), 125-170. https://doi.org/10.1016/S0733-558X(05)23004-5

Thornton, P., Ocasio, W., \& Lounsbury, M. (2012). The Institutional Logics Perspective - A new approach to culture, structure and process. Oxford University Press, Oxford, UK. https://doi.org/10.1093/acprof:oso/ 9780199601936.001.0001

Timmermans, J., van der Heiden, S., \& Born, M. P. (2014). Policy entrepreneurs in sustainability transitions: Their personality and leadership profiles assessed. Environmental Innovation and Societal Transitions, 13, 96-108. https://doi.org/10.1016/j.eist.2014.06.002

Truffer, B., Rohracher, H., \& Markard, J. (2009). The Analysis of Institutions in Technological Innovation Systems - A Conceptual Framework Apllied to Biogas Development in Austria. Conference paper at DRUID conference: Copenhagen Business School, 7.

Tushman, M. L., \& Scanlan, T. J. (1981). Boundary Spanning Individuals: Their Role in Information Transfer and Their Antecedents. Academy of Management Journal, 24(2), 289-305. https://doi.org/10.2307/255842

Van den Bergh, J. C. J. M., Truffer, B., \& Kallis, G. (2011). Environmental innovation and societal transitions: Introduction and overview. Environmental Innovation and Societal Transitions, 1(1), 1-23. https://doi.org/10. 1016/j.eist.2011.04.010

Verbong, G., \& Loorbach, D. (Eds.) (2012). Governing the Energy Transition. Routledge, New York.

Westley, F., Tjornbo, O., \& Schultz, L. (2013). A theory of transformative agency in linked social-ecological systems. Ecology and Society, 18(3), 27. https://doi.org/10.5751/ES-05072-180327

Williams, P. (2002). The Competent Boundary Spanner. Public Administration, 80(1), 103-124. https://doi.org/10. $1111 / 1467-9299.00296$

Williams, P. (2010). Special Agents: The Nature and Role of Boundary Spanners. Paper to the ESRC research seminar series: Collaborative futures: new insights from intra and inter-sectoral collaborations, University of Bermingham.

Williams, P. (2012a). Collaboration in Public Policy and Practice - Perspectives on boundary spanners. The Policy Press, Bristol, UK.

Williams, P. (2012b). We are all boundary spanners now? International Journal of Public Sector Management, 26(1), 17-32. https://doi.org/10.1108/09513551311293417

Yin, R. (2009). Case Study Research: Design and Methods. Sage Publications, Thousand Oaks, California.

Zietsma, C., \& Lawrence, T. B. (2010). Institutional Work in the Transformation of an Organizational Field: The Interplay of Boundary Work and Practice Work. Administrative Science Quarterly, 55(2), 189-221. https://doi.org/10.2189/asqu.2010.55.2.189

\section{Note}

Note 1. Building on de Haan et al., 2014 and Nigam \& Ocasio, 2010 we define an organizational field as a network of organisations that interact frequently in the process of financing, delivering and regulating field specific services for the fulfilment of societal needs. This paper investigates the urban stormwater management field which represents a distinct set of actors who provide specific societal services related to flood and environmental protection. It is therefore distinct, but not entirely independent, of other fields such as the water supply or waste water management field which, in turn, are part of a broader public service provision field.

\section{Copyrights}

Copyright for this article is retained by the author(s), with first publication rights granted to the journal.

This is an open-access article distributed under the terms and conditions of the Creative Commons Attribution license (http://creativecommons.org/licenses/by/4.0/). 